\title{
Dilematis Perencanaan Karir Mahasiswa Akhir Pendidikan Agama Islam
}

\section{Dilemma of Career Planning Of Students End Islamic Religious Education}

\author{
Arfin Fuad Afdhol* \\ Pendidikan Agama Islam, Fakultas Ilmu Tarbiyah dan Keguruan, Universitas Islam \\ NegeriSunan Kalijaga Yogyakarta, Indonesia
}

Diterima: 20 Juni 2021; Direview: 02 Agustus 2021; Disetujui: 19 Agustus 2021

*CorespondingEmail: arcorrefinuadafdhol

\begin{abstract}
Abstrak
Tujuan dari penenlitian ini adalah untuk pendalaman secara nyata terkait faktor utama ketidakmatangan perencanaan karir mahasiswa. Sehingga dapat menjadi evalusi bagi pengembangan proses Pendidikan di program studi Pendidikan agama islam yang berorientasi pada kematangan karir.Penelitian ini merupakan penelitian metode kepustakaan (library research) dan metode yang disebut gerakan ganda (double movement) yang mana menurut Sutrisno (2006) inti dari metode penelitian menggunakan prinsipprinsip Al-qur'an yang kemudian diaplikasikan dalam kehidupan modern.Adapun sumber dari penelitian ini dibagi menjadi dua, yaitu primer dan sekunder. Sumber primer yaitu teks Alqur'an yang berkaitan dengan tema penelitian, sedangkan sumber skunder berkaitan dengan buku, jurnal, website, penelitian terdahulu dan literatur yang mempunyai relevansi dengan tema penelitian ini. Hasil penelitian menunjukan bahwa perlunya penerapan surat Al-haysr ayat 18 yang mana menjelaskan perlunya manusia untuk selalu intropeksi diri atas apa yang sudah dilakukan hari ini untuk kehidupan esok yang lebih baik. Kata Kunci: Karir;Mahasiswa Akhir; Pendidikan Agama Islam
\end{abstract}

\begin{abstract}
The purpose of this research is to deepen in real terms the main factors of the unmatangan of student career planning. So that it can be an evalution for the development of the Education process in islamic religious education courses oriented to career maturity. This research is a research method library (library research) and a method called double movement which according to Sutrisno (2006) the core of the research method using the principles of the Qur'an which is then applied in modern life. The source of this study is divided into two, namely primary and secondary. The primary source is the Text of alqur'an relating to the theme of research, while the source of the secondary is related to books, journals, websites, previous research and literature that has relevance to the theme of this research. The results showed that the need for the application of surah Al-haysr verse 18 which explains the need for man to always intropeksi himselffor what has been done today for a better tomorrow.
\end{abstract}

Keywords: Career;Final Student;Islamic Religious Education

How to Cite: Afdhol, A. F. (2021). Dilematis Karir Mahasiswa Akhir Pendidikan Agama Islam. Journal of Education, Humaniora and Social Sciences (JEHSS). 4 (2): 1122-1128. 


\section{PENDAHULUAN}

Mahasiswa tingkat akhir selalu dihadapkan kepada tuntunan untuk memiliki pilihan karir yang bagus. Pada masa akhir perkuliahan, mahasiswa mulai memikirkan berbagai pilihan pekerjaan mulai menjadi guru, dosen, pengusaha, wiraswasta, bahkan PNS. Umumnya pilihanpilihan tersebut muncul dari lingkungan sekitar atau keadaan seperti orang tua, teman sebaya, dan lowongan pekerjaan yang ada.

Keadaan tersebut menandakan kurang matangnya mahasiswa dalam merencanakan karir, yang berdampak pada tidak siapnya mahasiswa untuk memasuki dunia kerja. Di satu sisi ditengah arus globalisasi yang memberikan banyaknya pilihan karir yang menarik bagi generasi milenial saat ini, namun hal itu kembali lagi pada kesiapan mahasiswa untuk menghadapi peluang, tantangan, dan konsekuansi yang ada.

Adanya fenomena para lulusan yang belum sepenuhnya mempertimbangkan kemampuan, minat, dan kepribadiannya dalam memilih suatu pekerjaan. Kecenderungan mereka dalam menentukan pekerjaan yang dipilihnya berdasarkan rasa khawatir dan cemas bila terlalu lama menganggur, rasa malu pada lingkungan sekitar terutama jika belum memperoleh pekejaan, dan adanya tuntunan moral dari orang tua.(Rahardjo, 2018) Hal itu didukung survei yang diberitakan oleh Republika. co.id yang diterbitkan pada 6/5/2021 yang diambildarikutipan MenteriKetenagakerjaan, Ida Fauziah yang menyatakan profil ketenagakerjaan, 85 persen warga Indonesia yang bekerja dari kalangan Pendidikan jenjang SMA. Sekitar 56 persen berasal dari lulusan SMP. Bahkan, ada pula yang tidak lulus SMP tapi masuk dalam profil ketenagakerjaan di Indonesia. Ida juga memaparkan angka penangguran saat ini berasal dari lulusan perguruan tinggi. (Republika.co.id). Hal itu menandakan bahwa lulusan perguruan tinggi saat ini belum siap terjun dalam dunia kerja.

Kondisi serupa juga terjadi pada mahasiswa program studi bimbingan dan konseling di Universitas PGRI Palembang, tahun kelulusan 2018/2019. Berdasarkan tracer study, ditemukan baru sekitar 30\% alumnus yang langsung mendapakat pekerjaan, 10 alumnus merencanakan untuk studi lanjut (Program Magister/Profesi Konselor), dan 60\% alumnus masih mencari pekerjaan, yang didominasiolehmahasiswalaki-laki (Surtiyoni, 2020)

Persoalan utama adalah, sebagai mahasiswa dari Fakultas Ilmu Tarbiyah dan Keguruan idealnya mahasiswa memiliki fokus karir yang pasti yaitu menjadi guru Pendidikan agama islam di sekolah. Namun, menjadi guru terutama honerer bukanlah pilihan utama mereka. Hal itu menandakan kurang matangnya perencanaan karir yang dilakukan oleh mahasiswa.

Banyak faktor yang membuat ketidak matangan karir. Secara internal, kegalauan pilihan karir dikarenakan oleh self estem yang rendah, pemahaman akan kemampuan, minat, kepribadian, dan prestige, serta konsep individu secara umum. Sedangkan faktor eksternal yaitu faktor keluarga dapat berpengaruh kepada pemilihan karir, terutama dalam memilih bidang pekerjaan yang diinginkan, faktor sosial ekonomi, mencakup lingkungan gaya hidup, dan ekspetasipenghasilan yang diinginkan (Sayekti, 2020).

Sebagaimana yang diungkapkan oleh (Jatmika \& Linda, 2017) dari hasil analisis konten hasil kuesioner terbuka menunjukkan arti karir bagi siswa adalah: menentukan masa depan, pekerjaan, dan simbol keberhasilan. Beberapa siswa melakukan perencanaan karir seperti belajar, mendapatkan pengalaman kerja, dan mencari informasi pekerjaan. Masalah yang mereka rasakan dalam perencanaan karier seperti tidak memiliki pengalaman kerja, merasa bingung untuk memilih, dan modal finansial untuk berbisnis. Mereka juga menyebutkan kekuatan mereka sendiri adalah kompetensi, keterampilan, sikap dan pengalaman kerja. Beberapa kelemahan yang mereka rasakan seperti kurangnya kompetensi dan keterampilan, memiliki kurangnya sikap kerja, dan kurangnya kepercayaan diri. Singkatnya, istilah terakhir siswa dipamerkan kematangan karir sedang hingga tinggi. Pengalaman kerja dan evaluasi kekuatan dapat memprediksi kematangan karir mahasiswa.

Hasil (Abidin \& Fitriyah, 2017) penelitian terkait pengaruh internal dan eksternal locus of control dengan kematangan karir pada mahasiswa Fakultas Agama Islam Universitas Singaperbangsa Karawang menujukkan hasil bahwa internal locus of control memiliki hubungan 
Arfin Fuad Afdhol. Dilematis Karir Mahasiswa Akhir Pendidikan Agama Islam.

yang positif dan signifikan dengan kematangan karir. Semakin tinggi internal locus of control siswa artinya semakin tinggi kematangan karir pada mahasiswa. Selain itu ia menyebutkan bahwa sebagian besar mahasiswa tingkat akhir secara umum masih berada pada taraf belum siap untuk menentukan arah karirnya. Dilihat berdasarkan kemampuannya untuk melakukan eskplorasi karir, membuat perencanaan, mengambil keputusan dan juga wawasannya mengenai dunia kerja. Padahal idealnya, mahasiswa tingkat akhir sudah siap menentukan arah karir sesuai dengan tugas perkembangannya. (Pratama, 2017) dalam penelitiannya memperoleh hasil bahwa mayoritas mahasiswa memaknai karir sebatas sebuah pekerjaan untuk mendapatkan penghasilan, sehingga mereka cenderung akan mempersiapkan diri hanya untuk bekerja bukan berkarir. Hal ini dapat disintesakan dengan pengalaman implementasi program, dimana program pembinaan karir yang paling diminati adalah persiapan menghadapi proses rekruitmen kerja yang notabene secara konkret untuk mengajarkan tentang keterampilan memasuki dunia kerja, sedangkan programprogram dengan konteks perencanaan karir seperti ; topik life plan dan soft skills sangat rendah peminatnya.

Sejalan dengan hal tersebut, hasil analisis wawancara yang dilakukan (NUGRAHA, 2018) mengenai problem penentuan karir mahasiswa tingkat akhir dengan kesimpulan sebagai berikut: 1) Pada penentuan karir, mahasiswa tingkat akhir dihadapkan dengan problem/masalah. Sehingga mahasiswa tingkat akhir belum mampu menentukan arah karir, mau apa dan kemana setelah mendapatkan gelar sarjana (S1) Bimbingan dan Konseling; 2) Pada penentuan karir, mahasiswa tingkat akhir memiliki usaha dalam menghadapi problem penentuan karirnya. Sehingga mahasiswa tingkat akhir mampu membuat perencanaan karir dengan jelas dan mampu merealisasikan penentuan karirnya pasca wisuda; 3) Pada penentuan karir, mahasiswa tingkat akhir dihadapkan dengan kendala. Sehingga membatasi ruang gerak mahasiswa tingkat akhir dalam membuat perencanaan dan keputusan karirnya serta kesulitan mendapatkan informasi tentang karir dan pekerjaan.

Analisis deskriptif (Sayekti, 2020) menunjukkan bahwa mahasiswa semester akhir memiliki kesiapan yang tinggi dalam menghadapi dunia kerja, baik laki-laki maupun perempuan. Indikator menuju kesiapan karier yaitu spesifikasi karir, implementasi karir, kristalisasi pekerjaan dan spesifikasi pekerjaan dengan hasil tinggi. Sehingga dapat disimpulkan bahwa mahasiswa tingkat akhir Universitas Ivet sudah siap dalam mennentukan karier yang dipilih setelah lulus.

Berdasarkan hasil penelitian sebelumnya maka dapat diperjelas bahwa mahasiswa telah memiliki kemantapan karir dalam hidupnya. Hal ini sejalan dengan penjelasan dari penelitian (Violina, 2018) yang mendefinisikan bahwa kematangan karir sebagai kemampuan individu dalam membuat suatu pilihan karir yang realistis dan stabil. Mahasiwa menyadari akan apa yang dibutuhkan dan membuat suatu perkiraan ketika akan menentukan atau memutuskan karir dalam bidang tertentu. Pada tahapan usia dewasa, mahasiswa sudah berada pada kondisi dimana individu mulai menilai diri, mencoba peran, dan mengeksplorasi pekerjaan yang mungkin dimasuki setelah selesai atau lulus kuliah, melakukan aktivitas di waktu luang, dan bahkan bekerja penuh waktu (part time work), bahkan juga dapat memegang satu peran pekerjaan. Untuk itu mempersiapkan kematangan karir yang tepat sangatlah penting. Tingkat kematangan karir mahasiswa tidak terlepas dari tahaptahapan pembelajaran mahasiswa. Tahapan kematangan karir terletak pada kemandirian dan kemampuan mahasiswa dalam mengolah dan menggali potensi dalam dirinya (Nurrillah, 2017). Pemilihan karir ditentukan pada pandangan sektor publik dengan melihat pada keamanan, keuangan, serta jaminan hari tua atau masa depan (Nurhayati et al., 2016). Dengan pandangan tersebut, mahasiswa mampu menentukan kemana arah karir yang diinginkan berdasarkan apa yang telah dipelajari.

Oleh karena itu penelitian ini bertujuan untuk pendalaman secara nyata terkait faktor utama ketidakmatangan perencanaan karir mahasiswa. Sehingga dapat menjadi evalusi bagi pengembangan proses Pendidikan di program studi Pendidikan agama islam yang berorientasi pada kematangan karir mahasiswa yingkat akhir. 


\section{METODE PENELITIAN}

Metode penelitian yang digunakan dalam penelitian ini yaitu metode kepustakaan (library research) dan metode yang disebut gerakan ganda (double movement) yanga mana menurut Sutrisno (2006) (dalam (Fazlurrahman, 2018)) inti dari metode penelitian menggunakan prinsipprinsip Al-qur'an yang kemudian diaplikasikan dalam kehidupan modern. Adapun sumber dari penelitian ini dibagi menjadi dua, yaitu primer dan sekunder. Sumber primer yaitu teks Alqur'an yang berkaitan dengan tema penelitian, sedangkan sumber skunder berkaitan dengan buku, jurnal, website, penelitian terdahulu dan literatur yang mempunyai relevansi dengan tema penelitian ini.

Menurut Rahman (1964) dalam (Fazlurrahman, 2018) adapun langkah-langkah penelitian yang menggunakan metode gerakan ganda (double movement) yaitu akan dipaparkan sebagai berikut:Yang pertama dari dua gerakan (gerakan ganda atau double movement) yang disebutkan diatas terdiri daridualangkahyaitu:Langkahpertama, memahami Al-qur'an secara utuh maupun dalam Batasan-batasan ajaran spesifik yang merupakan respon terhadap situasi-situasi spesifik. Langkah kedua, menggeneralisasikan jawaban-jawaban spesifik tersebut dan menyatakannya sebagai pernyataan-pernyataan yang memiliki tujuan moral umum yang disarikan dari teks spesifik pada Al-qur'an dalam sinaran latar belakang sosio historis dan rationes legis yang sering dinyatakan.

Sementara gerakan pertama dimulai dari hal-hal spesifik dalam Al-qur'an ke panggalian dan sistematisasi prinsip-prinsip umum, nilai-nilai, dan tujuan-tujuan jangka panjangnya, maka gerakan kedua harus dilakukan dari pandangan umum ke pandangan spesifik yang harus diformulasikan dan direalisasikan sekarang. Maksudnya, yang umum itu harus ditubuhkan ke dalam konteks sosio-historis konkret dewasa ini. Hal ini membutuhkan kajian cermat terhadap situasi dewasa ini dan analisis terhadap berbagai unsur komponennya sehingga kita bisa menilai situasi sekarang dan mengubahnya sejauh diperlukan, serta mendeterminasi prioritas-prioritas baru untuk mengimplementasikan nilai-nilai Al-qur'an.

\section{HASIL DAN PEMBAHASAN}

Fenomen yang dihadapi mahasiswa PAI akhir-akhir ini yaitu adanya dilematis dalam perencanaan karir. Perencanaan karir yang belum ada sehingga berdampak pada banyaknyaangkapengangguran di negara inikhususnya pada lulusan peguruan tinggi. Apabila menelaah lebih dalam ada beberapa faktor yang menyebabkan beberapa mahasiswa PAI masihragudalamperencanaankarirseusai lulus dari perguruan tinggi, diantaranya: banyaknya pilihan karir di era ini, self estemyang rendah, kurangnya pemahamanakankemampuandiri, kurangnyapemahamanminat, kepribadian atau prestige, konsep individu secara umum, sosial ekonomi, lingkungan gaya hidup, dan ekspetasi penghasilan yang diinginkan. Dari beberapa faktor yang disebutkan tadi menurut (Andriani \&Fatma 2018) faktor utama adanya hambatan dalam perencanaan karir bagi mahasiswa yaitu adanya rasa malas pada diri mahasiswa sehingga berdampak pada adanya dilematis pada mahasiswa. Adanya rasa malas ini seharusnya membuat mahasiswa untuk berfikir lebih jauh untuk mengatasi permasalahan yang ada, apabilai mahasiswa hanya melibatkan diri pada masalahini yang mana tidakmemanfaatkanerwaktu untuk aktivitas yang tidak jelas maka berakibat pada penentuan karir yang masih belum jelas. Padahal waktu yang kosong alangkah lebih baiknya digunakan untuk aktivitas yang akan menunjang karir mahasiswa kedepannya.

Apabila ditinjau dari sisi arti "karir" adalah suatu rangkaian perubahan nilai, sikap, dan perilaku serta motivasi yang terjadi pada setiap individu selama rentang waktu kehidupannya untuk menemukan secara jelas keahlian, tujuan karir dan kebutuhan untuk pengembangan, merencanakan tujuan karir, dan secara berkelanjutan mengevaluasi, merevisi, dan meingkatkan rancangannya. (Nindya et al., 2020). Islam mengartikan karir merujuk dalam organisasi kerja. Tentunya konsep organisasi kerja yang dimaksud tidak hanya pada organisasi bisnis semata. Lebih 
Arfin Fuad Afdhol. Dilematis Karir Mahasiswa Akhir Pendidikan Agama Islam.

luas lagi bisa terjadi pada lapangan organisasi sosial dan keagamann yang terbingkai secara 1126iam aha1126. Surat Al-haysr ayat 18 merupakan salah satu prinsip dalam melakukan perkembangan karir. Hal itu dapat dilihat dari terjemahannya yang berbunyi: "Hai orang-orang yang beriman, bertakwalah kepada Allah dan hendaklah Setiap diri memperhatikan apa yang telah diperbuatnya untuk hari esok (akhirat); dan bertakwalah kepada Allah, sesungguhnya Allah maha mengetahui apa yang kamu kerjakan".

Dalam tafsirnya Ibnu Katsir menjelaskan taqwa sendiri diapliaksikan dalam dua hal, yaitu menepati aturan Allah dan menjauhkan diri dari larangan-Nya. Jadi, tidak bis akita mengatakan "saya telah meneggakanshalat", setelah itu berbuat maksiat Kembali. Karena makna takwa sendiri saling bersinergi, tidak dapat dipisahkan. Begitu pula penjelasan Al-qurthubi yang menyatakan bahwa perintah taqwa (pada ayat ini) bermakna: "Bertaqwalah pada semua perintah dan larangannya, dengan cara melaksanakan kewajiban-kewajiban-Nya yang dibebankan oleh Allah kepada diri kita, sebagai orang yang beriman, dan menjauhi larangan-larangan Allah, yang secara keseluruhan harus kita tinggalkan dalam keseluruhan apek kehidupan kita". (Harnita et al., 2018)

Pada potongan ayat selanjutnya inilah yang memiliki makna dan motivasi mendalam terkait intropeksi diri dan pentingnya dalam mengatur waktu untuk hari esok. Allah berfirman dalam penggalan surat Al-haysr ayat 18 yang berbunyi:

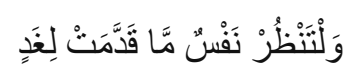

"dan hendaklah setiap orang memperhatikan apa yang telah diperbuatnya untuk hari esok (akhirat)"

Menurut beberapa mufassir kata "ghad"memiliki banyak arti, Al-qurthubi menjelaskan yang dimaksud kata tersebut adalah hari kiamat. Kata-kata ghad sendiri dalam bahasa arab artinya besok.(Hosaini \& Kurniawan, 2019) Beberapa ahli ta'wil menyatakan dalam beberapa Riwayat: Allah senantiasa mendekatkan hari kiamat hingga menjadikannya seakan terjadi besok, dan besok adalah hari kiamat. Ada juga yang mengartikan "ghad" sesuai dengan makna aslinya, yakni besok. Hal ini bisa diartikan juga bahwa kita diperintahkan untuk selalu melakukan intropeksi dan perbaikan guna mencapai masa depan yang baik. Melihat masa lalu, yakni dijadikan pelajaran bagi masa depan atau juga menjadikan pelajaran masa lalu sebuah investasi besar untuk masa depan.(Jordy, 2019)

Dalam kitab Tafsir Ibnu Katsir, ayat ini disamakan dengan perkataan "haasibuuanfusakumqabla an tuhaasabuu" Hisablah (intropeksi) diri kalian sebelum nanti kalian dihisab (di hari akhir).

Potongan ayat selanjutnya Allah 1126iam ah mengulang untuk kedua kalinya kalimat yang artinyasamabertaqwalahkepada Allah. Dalam kaidah bahasa arab apabila ada suatu kata yang diulang sebanyak dua kali dalam satu susunan kalimat maka kalimat tersebut mengandung unsur penekanan atau sungguh-sungguh. Al-Qhurtubi menjelaskan bahwa kalimat (wattaqullah) memberikan penjelasan bahwa kalimat (wattaqullah) pertama bisa dipahami sebagai perintah untuk bertaubat terhadap apa pun perbuatan dosa yang pernah kita lakukan, sedangkan pengulangan kalimat wattaqullahuntuk kedua kalinya memberikan pengertian agar kita berhatihati terhadap kemungkinan perbuatan maksiat yang bisa terjadi dikemudian hari setelah kita bertaubat, karena pada hakikatnya jin tidak akan pernah berhenti menggoda manusia.(alQhurthubi 2008)

Adanya penjelasan ayat diatas menjelaskan bahwa pentingnya seseorang melihat apa yang telah diperbuatnya di masa laluuntuk kesuksesan dan kebahagian masa depan. Allah senantiasa memberi motivasi kepada manusia untuk selalu menanamkan kebaikan denga amal shaleh. Dengan waktu yang diberikan pada saat ini sudah seharusnya manusia selalu berfikir untuk mengerjakan segala hal yang berorientasi pada hal kebaikan. Perlu diingat penciptaan manusia di muka bumi ini hanya untuk beribadah.

Penjelasan ayat diatas juga menjelaskan bahwasannya kehidupan itu terbagi menjadi tiga yaitu masa lalu, saat ini, dan masa yang akan datang. Dalam ayat tersebut Allah mewanti-wanti kepada manusia untuk mengintropeksi perilakunya di masa lalu untuk kesuksesan hari esok. Sedangkan saat ini adalah waktu yang hanya dibeikan untuk manusia, dengan cara 
memanfaatkannya dan mengatur waktu sebaik-baiknya adalah hal yang paling utama untuk mencapai kesuksesan yang akan diraih. Hal ini berlaku pada diri mahasiswa saat ini, apabila ingin sukses dunia akhirat maka tergantung jerih payahnya dan banyak waktu yang digunakan untuk belajar.

Tentu yang dimaksud Allah dalam ayat ini juga adalah timbulnya kebaikan yang mengarah kepada kesuksesan akhirat yang abadi. Hari kiamat dikatakan seperti hari esok dan sangat dekat, tentu ibadah dan seluruh pekerjaan yang dilaksanakan pada hari ini haruslah dengan cara terbaik dan niat yang terbaik. Dalam ayat tersebut Allah menutup firmanNya dengan mengatakan bahwa 1127iam aha mengetahui apapun usaha yang dilakukan.

Kemudian langkah kedua dalam menyelesaikan masalah dengan double movement menggeneralisasikan jawaban-jawaban tersebut dan menyatakan sebagai pernyataan-pernyataan yang memiliki tujuan moral umum. Sudah jelas bahwa pernyataan-pernyataan diatas yang berkaitan dengan pekembangankarir perlunya manusia dalam mengintropeksi diri dan mengunakan waktu yang ada dengan baik (menanam kebaikan).

Dengan melihat perkembangan karir di era saat ini yang begitu luas, dan banyaknya lulusan setiap tahunnya yang mencari pekerjaan seharusnya para mahasiswa lebih pada menggunakan waktu sebaik-baiknya, dan mengintropeksi diri atas pencapaian apa yang telah dilakukan saat ini, dengan begitu permasalahan yang ada mahasiswa akhir saat ini seharusnya dapat teratasi dengan baik.

Khusunya pada jurusan Pendidikan agama islam yang sudah memiliki tujuan karir yang jelas, yaitu menjadi guru. Adapun adanya permasalahan guru PAI saat ini yaitu terkait dengan gaji yang begitu kecil, seharusnya membuat para mahsiswa juga berfikir kedepan untuk mencari pekerjaan di luar menjadi guru, atau kerjaan sampingan. Menurut (Jandra \& Djamil, 2018)Pada hakikatnya lulusan jurusan Pendidikan agama islam dapat memilih dan memperoleh profesi di luar bidang ini, asal mampu bersaing dengan sarjana lain. Sarjana Pendidikan agama islam (PAI) tidak melulu lulusannya harus menjadi, guru ngaji, kyai, ustad/ustadzah, da'i/da'iah, qari'/qari'ah. Idealnya sarjana Pendidikan agami slam (PAI) juga bisa jadi pengusaha yang selalu menerapkan nilai-nilai keislaman, bisa pula menjadi politisi yang mampu menerapkan nilai-nilai keislaman, wirausahaan yang islami, pegawai yang islami, dan sebagainya.

Intinya adalah apapun profesinya, sarjana Pendidikan agama islam harus membawa panjipanji islam, mampu berdakwah di berbagai lini kehidupan. Namanya dakwah tidak terbatas hanya ceramah, khutbah, halaqah, dan mendirikan majlis-majlis maulid. Tetapi setiap profesi (yang tidak bertentangan dengan syar'at agama) bisa menjadi ladang dakwah melalui nilai-nilai islam yang disisipkan dalam profesi tersebut.(Jandra \& Djamil, 2018)

\section{SIMPULAN}

Apabila menelaah lebih dalam ada beberapa faktor yang menyebabkan beberapa mahasiswa PAI masih ragu dalam perencanaan karir seusai lulus dari perguruan tinggi, diantaranya: banyaknya pilihan karir di era ini, self estemyang rendah, kurangnya pemahaman akan kemampuan diri, kurangnya pemahaman minat, kepribadian atau prestige, konsep individu secara umum, sosial ekonomi, lingkungan gaya hidup, dan ekspetasi penghasilan yang diinginkan.Pentingnya seseorang melihat apa yang telah diperbuatnya di masa laluuntuk kesuksesan dan kebahagian masa depan. Seharusnya para mahasiswa lebih pada menggunakan waktu sebaik-baiknya, dan mengintropeksi diri atas pencapaian apa yang telah dilakukan saat ini, dengan begitu permasalahan yang ada mahasiswa akhir saat ini seharusnya dapat teratasi dengan baik. 
Arfin Fuad Afdhol. Dilematis Karir Mahasiswa Akhir Pendidikan Agama Islam.

\section{DAFTAR PUSTAKA}

Abidin, J., \& Fitriyah, U. (2017). PENGARUH LOCUS OF CONTROL TERHADAP KEMATANGAN KARIR MAHASISWA FAKULTAS AGAMA ISLAM. Wahana Karya Ilmiah Pendidikan, 2:(1), 158-167.

Fatma, A. dan. (2018). Hubungan Antara Distress dan Dukungan Sosial dengan Proktanisasi Akademis Pada Mahasiswa dalam Menyusun Skripsi. Jurnal Talenta Psikologi, 2:(20), 38-49.

Fazlurrahman, M. (2018). Modernisasi Pendidikan Islam: Gagasan Alternatif Fazlur Rahman. TA'LIM: Jurnal Studi Pendidikan Islam, 1:(1), 73-89.

Harnita, L., Yusro, N., \& Yunita, N. (2018). Makna Takwa Perbandingan Tafsir Klasik dan Modern (Kajian Tafsir Ibnu Katsir dan Al-Misbah). IAIN Curup.

Hosaini, H., \& Kurniawan, S. (2019). Manajemen Pesantren dalam Pembinaan Umat. Edukais: Jurnal Pemikiran Keislaman, 3:(2), 82-98.

Jandra, M., \& Djamil, A. (2018). Pendidikan islam dan lapangan kerja. 2, 121-133.

Jatmika, D., \& Linda, L. (2017). Gambaran kematangan karir pada mahasiswa tingkat akhir. Psibernetika, 8:(2), 185-203.

Jordy, M. (2019). Al-Itisar dalam Al-qur'an (studi tentang tafsir tematik). IAIN BENGKULU.

Nindya, N. N., Kiswantoro, A., \& Hidayati, R. (2020). Layanan informasi melalui media animasi untuk meningkatkan kematangan karir peserta didik. Jurnal Prakarsa Paedagogia, 2(2).

Nugraha, B. A. (2018). Problem Penentuan Karir Mahasiswa Tingkat Akhir (Studi Pada Mahasiswa Bimbingan Dan Konseling Iain Batusangkar).

Nurhayati, E., Respati, T., \& Budiman, B. (2016). Pilihan Karier Lulusan Program Pendidikan Profesi Dokter Universitas Islam Bandung Tahun 2015. Global Medical \& Health Communication, 4:(2), 87-92.

Nurrillah, S. A. L. (2017). Program Bimbingan Karir untuk Meningkatkan Kematangan Karir Mahasiswa. Journal of Innovative Counseling: Theory, Practice, and Research, 1(01).

Pratama, M. J. (2017). Apa Makna Karir Bagimu?: Pemaknaan Kata Karir pada Mahasiswa Tingkat Akhir Mahasiswa Universitas Lampung. Jurnal Pendidikan Progresif, 7:(2), 101-105.

Rahardjo, L. dan. (2018). Hubungan Antara Kecerdasan Emosional dengan Kemtangan Karir Pada Mahasiswa Universitas Muhammadiyah Purwekerto yang Menempuh Skripsi.

Sayekti, S. (2020). Gambaran Kematangan Karir Mahasiswa Tingkat Akhir Universitas Ivet. 3:(2), 113-124.

Surtiyoni, E. (2020). Hambatan Kematangan Perencanaan Karir Mahasiswa Sebagai Generasi Millenial. 7:(1), $1-6$.

Violina, E. I. (2018). Gaya Pembuatan Keputusan Karier Mahasiswa Baru Program Studi Bimbingan Konseling Universitas Muhammadiyah Sumatera Utaratahun Ajaran 2017-2018. Jurnal Penelitian Bimbingan Dan Konseling, 3(1). 